Western University

Scholarship@Western

Aboriginal Policy Research Consortium International (APRCi)

2008

\title{
The International Management of Aboriginal Whaling
}

Michael F. Tillman

Follow this and additional works at: https://ir.lib.uwo.ca/aprci

Part of the Environmental Policy Commons

Citation of this paper:

Tillman, Michael F., "The International Management of Aboriginal Whaling" (2008). Aboriginal Policy Research Consortium International (APRCi). 201.

https://ir.lib.uwo.ca/aprci/201 
This article was downloaded by: [University of Western Ontario]

On: 07 December 2012, At: 11:55

Publisher: Taylor \& Francis

Informa Ltd Registered in England and Wales Registered Number: 1072954 Registered office: Mortimer House, 37-41 Mortimer Street, London W1T 3J H, UK

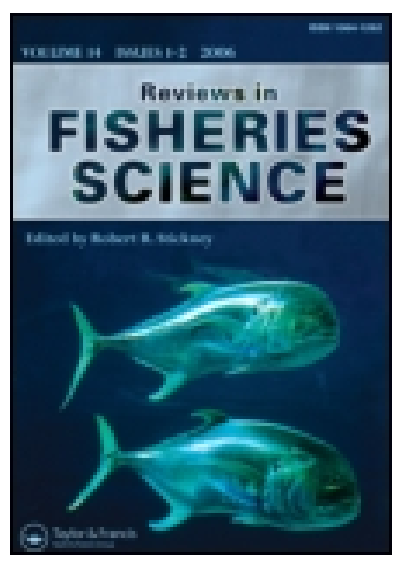

\section{Reviews in Fisheries Science}

Publication details, including instructions for authors and subscription information: http:// www. tandfonline.com/loi/ brfs20

\section{The International Management of Aboriginal Whaling}

Michael F. Tillman ${ }^{a}$

${ }^{a}$ Center for Marine Biodiversity and Conservation, Scripps Institution of Oceanography, La Jolla, California, USA

Version of record first published: 09 May 2008.

To cite this article: Michael F. Tillman (2008): The International Management of Aboriginal Whaling, Reviews in Fisheries Science, 16:4, 437-444

To link to this article: http:// dx. doi.org/ 10.1080/ 10641260802013932

\section{PLEASE SCROLL DOWN FOR ARTICLE}

Full terms and conditions of use: http://www.tandfonline.com/page/terms-and-conditions

This article may be used for research, teaching, and private study purposes. Any substantial or systematic reproduction, redistribution, reselling, loan, sub-licensing, systematic supply, or distribution in any form to anyone is expressly forbidden.

The publisher does not give any warranty express or implied or make any representation that the contents will be complete or accurate or up to date. The accuracy of any instructions, formulae, and drug doses should be independently verified with primary sources. The publisher shall not be liable for any loss, actions, claims, proceedings, demand, or costs or damages whatsoever or howsoever caused arising directly or indirectly in connection with or arising out of the use of this material. 


\title{
The International Management of Aboriginal Whaling
}

\author{
MICHAEL F. TILLMAN \\ Center for Marine Biodiversity and Conservation, Scripps Institution of Oceanography, La Jolla, California, USA
}

\begin{abstract}
Prior to the development of commercial whaling, several indigenous communities undertook hunts of whales to fulfill their subsistence needs. Fortunately, the two international conventions that implemented the regulation of commercial whaling did not lose sight of the needs of these aboriginal communities. How this was done, as well as the eventual evolution of the management of aboriginal whaling, is summarized in this review. The record shows that, whether in terms of exempting these aboriginal hunts from required management actions or of setting precautionary catch limits for otherwise protected stocks, an overriding management principle has emerged wherein international managers have been willing to accept conservation risks for aboriginal hunts that they otherwise would not assume for commercial operations. Although these risks were accepted, it was done at the cost to the aboriginal hunters of undertaking conservation measures often not applied to commercial hunts. While it is not clear from the record whether this guiding principle arose explicitly or implicitly, it is nevertheless explicitly clear that it has been and continues to be applied, and successfully so, when considering the conservation of the affected stocks.
\end{abstract}

Keywords aboriginal whaling, conservation, depleted stocks, hunts, IWC, management, subsistence, whales

\section{INTRODUCTION}

Centuries, and possibly even millennia, prior to the development of commercial whaling, several indigenous communities undertook hunts of whales to fulfill their subsistence needs. (In his exhaustive review of the origins and nature of the ongoing aboriginal hunts, Reeves (2002) identified 12 such whaling operations, of which the International Whaling Commission (IWC) currently manages five: West Greenland; St. Vincent and the Grenadines; Northern Alaska, USA; Chukotka, Russia; Washington State, USA). Many of these subsistence hunts took species such as bowhead (Balaena mysticetus), gray (Eschrictius robustus), and humpback (Megaptera novaeangliae), whales that subsequently became the targets of commercial operations, especially during the early days when sailing vessels were used. Despite the relatively primitive gear used, these early commercial operations heavily exploited these target species and, in most cases, greatly depleted the stocks (IWC, 1981a). Eventually, as whaling gear improved (including the use of steam power and the harpoon gun that both enabled high seas operations), governments realized that commercial whaling had to come under international management in order to protect depleted stocks

Address correspondence to Michael F. Tillman, Center for Marine Biodiversity and Conservation, Scripps Institution of Oceanography, 8602 La Jolla Shores Drive, La Jolla, CA 92037. E-mail: mftillman@mac.com and provide for their recovery. Fortunately, the framers of the two international conventions that eventually implemented the regulation of commercial whaling did not lose sight of the needs of the aboriginal communities.

In his extensive historical reviews of the regulation of commercial and aboriginal whaling, former Secretary of the International Whaling Commission, Dr. Ray Gambell (1993, 1997), observed that international managers "... gave greater weight to the perceived dependence of the native communities on the hunt than to the status of the whale stock" and that aboriginal subsistence whaling is recognized as "... having a distinctive character which separates it from the larger-scale commercial whaling operations." The following review includes new, behind-the-scenes information from the International Whaling Conference of 1946, elucidates possible reasons for Dr. Gambell's observations, and provides insights into the historical development of international management for aboriginal whaling. To help clarify historical development, Table 1 provides a chronology of some of the key events affecting the management of aboriginal whaling.

\section{THE ORIGINS OF MANAGING ABORIGINAL WHALING}

The great expansion of commercial whaling began with the introduction of factory ships enabling high-seas operations, especially in the Antarctic. By the 1930-1931 season, no fewer 
Table 1 Chronology of some key events in the management of aboriginal whaling

\begin{tabular}{cc}
\hline Year & \multicolumn{1}{c}{ Event } \\
\hline 1931 & $\begin{array}{c}\text { League of Nations draws up Convention for the Regulation of } \\
\text { Whaling that includes protection of right whales and exemption } \\
\text { for aboriginal hunts. }\end{array}$ \\
1937 & $\begin{array}{c}\text { Conference of Parties to 1931 Convention extends protection to } \\
\text { gray whales. }\end{array}$ \\
1946 & $\begin{array}{c}\text { International Conference draws up International Convention for the } \\
\text { Regulation of Whaling, establishing the International Whaling } \\
\text { Commission. }\end{array}$ \\
1949 & $\begin{array}{c}\text { First Annual Meeting of the International Whaling Commission } \\
\text { (IWC). }\end{array}$ \\
1954 & $\begin{array}{c}\text { IWC protects the North Atlantic humpback. } \\
\text { IWC provides exemption to allow Greenlanders to take North } \\
\text { Atlantic humpbacks. }\end{array}$ \\
1964 & $\begin{array}{l}\text { IWC amends the exemption for gray and right whales. } \\
\text { IWC revokes and then restores the Alaska Eskimo hunt for } \\
\text { bowhead whales. }\end{array}$ \\
1982 & $\begin{array}{c}\text { IWC adopts into the schedule a formal aboriginal management } \\
\text { scheme while also adopting a moratorium on commercial } \\
\text { whaling. }\end{array}$ \\
1987 & $\begin{array}{c}\text { IWC accords aboriginal status to St. Vincent and the Grenadines for } \\
\text { its Bequian hunt for North Atlantic humpback whales. }\end{array}$ \\
1988 & $\begin{array}{c}\text { IWC decides not to accord Japan's small-type coastal whaling } \\
\text { status under the aboriginal provisions. }\end{array}$ \\
1994 & $\begin{array}{c}\text { IWC adopts in principle the Revised Management Procedure for } \\
\text { commercial whaling and requests the Scientific Committee to } \\
\text { develop a comparable regime for aboriginal whaling. } \\
\text { IWC accords aboriginal status to the Makah Indian Tribe's hunt for } \\
\text { gray whales off Washington State. }\end{array}$ \\
\hline & \\
&
\end{tabular}

than 41 pelagic factories with over 200 catcher vessels operated in the Antarctic, and, from 1934 until WW II, the average catches exceeded 30,000 whales per year (combining all species but mainly blue, fin, and humpback whales) (Mackintosh, 1965). In recognition of the international nature of this pelagic hunt, the League of Nations drew up a Convention for the Regulation of Whaling in 1931, which came into force in 1935. It provided for, inter alia, the protection of right whales and females with calves, the licensing of whaling vessels, and the collection of statistics on catches (Mackintosh, 1965). In 1937, the Conference of Parties to the 1931 convention extended protection to the North Pacific gray whale, as well (Mackintosh, 1965).

Since the provision that protected right whales would also have covered bowhead whales (at that time variously called Arctic right whales and Greenland right whales), it would have prevented aboriginal hunts by Greenlanders and by Canadian and Alaskan Eskimos for that species. Moreover, the extension of protection to gray whales would have prevented the hunt for that species by native hunters in the Russian far east. The framers intended that the 1931 convention would apply solely to commercial operations (International Whaling Conference, 1946), and therefore included another provision specifically exempting from the implementation of the convention "aborigines dwelling on the coasts of the territories of the High Contracting Parties," subject to four conditions (Wallace, 1994a). Two of these conditions greatly proscribed the available hunting gear that might be applied, requiring that aborigines "only use canoes, pirogues, or other exclusively native craft propelled by oars or sails" and that "they do not carry firearms." The remaining two provisions effectively prevented the commercial sale of the whale products. Thus, the 1931 convention marked the first time that the existence of aboriginal whaling was acknowledged and, through a specific exemption, made it possible for aboriginal hunters to take species that were forbidden to commercial operations. In doing so, the convention implicitly recognized the legitimacy of meeting the subsistence needs of aboriginal communities through small-scale hunts, provided that they were not driven by commercial incentives.

Following the failure of the 1931 convention (Gambell (1993) discusses reasons for its demise) and after WW II, whaling nations met in Washington, DC, in 1946 to draw up the International Convention for the Regulation of Whaling. The 1946 convention established the International Whaling Commission (IWC), an executive body that formulates regulatory measures and oversees their application, and incorporated a schedule of regulations that can be easily amended. It is important to stress that the new convention, under terms of its 1st Article, explicitly included the schedule as one of its integral parts and stated that all references to "convention" should be understood as including the schedule and any of its subsequent amendments (Wallace, 1994b).

The verbatim minutes of the negotiations that led to the 1946 convention indicate that it drew heavily from the provisions of the 1931 convention, including the continuation of protections for depleted right and gray whales (International Whaling Conference, 1946). The Russian and Canadian delegates intervened during the 1946 proceedings to indicate their concerns with the draft language for protecting right and gray whales in paragraph 1 of the schedule, as it did not provide exemptions for aboriginal hunts (International Whaling Conference, 1946). Although other delegates indicated that the new convention would apply only to commercial operations and, that in any event, the aboriginal exemption of the 1931 convention would still apply, the Russian and Canadian delegates stated their views that the interests of their respective aboriginal peoples would not be covered because they used weapons and gear that was prohibited by the special conditions stipulated in the 1931 exemption. Namely, due to the difficult environmental conditions found in the Russian far north, the Russian government sent out a vessel to catch gray whales on behalf of its natives; Canada also noted that its natives needed weapons that were not allowed under the 1931 convention, presumably firearms, to kill bowheads.

To accommodate these concerns, the 1946 conference undertook two actions (International Whaling Conference, 1946). First, it adopted the following statement in the Final Act of the Washington Conference:

The International Whaling Conference supports and considers justified the request of the Delegation of the Union of Soviet Socialist Republics that the taking of gray whales in the Bering and 
Chukchi Seas should be permitted when the meat and products of such whales are to be used exclusively for local consumption by the aborigines of the Chokotsk and Korjaksk areas.

Second, the conference adopted the following compromise language for paragraph 2 of the schedule:

2. It is forbidden to take or kill gray whales or right whales, except when the meat of such whales is to be used exclusively for local consumption by the aborigines.

By these actions, the Washington Conference explicitly acknowledged aboriginal whaling and continued the idea established in 1931 that such hunts upon otherwise protected species were acceptable, provided that there was no explicit commercial incentive. That is, only local consumption by aborigines was allowed. While the 1946 convention therefore continued the principles established in the 1931 accords, it differed in that aboriginal whaling was not treated as an activity explicitly exempted from the operation of the convention. Instead, the provisions for aboriginal whaling were explicitly incorporated into the schedule, which meant that under Article I they were considered integral parts of the 1946 convention.

From 1948, when the convention entered into force, the first 30 years of managing aboriginal whaling proceeded under the basic 1946 exemption with the addition of only a few amendments to the schedule. In 1954, IWC initiated the first of several successive measures banning the commercial taking of humpback whales in the North Atlantic (Wallace, 1994c), which would have prevented the indigenous people of Greenland from occasionally taking that species for subsistence purposes (Kapel and Petersen, 1982). In 1961, however, IWC added a new exemption allowing Greenlanders to use small vessels to take up to 10 humpbacks annually (Wallace, 1994d). In 1962, commenting upon a Danish proposal in 1962 to broaden the application of the aboriginal exemption to include "local" people, Dr. Remington Kellogg, the then U.S. Commissioner, made the following clarification (Caulfield, 1997):

As chairman of the international conference that wrote the 1946 convention, I will say that the word aboriginal does not encompass any other people than indigenous residents, Eskimos, northern Indians, and Chukchis. This was the original idea.

In 1964, IWC amended the exemption for right and gray whales to allow contracting governments to take those species on behalf of their indigenous peoples (Wallace 1994e). This amendment to schedule paragraph 2 (shown below) made possible a government's use of a catcher vessel instead of traditional whaling gear; of course, as noted previously, the Russian delegate had first raised this issue during the 1946 proceedings (International Whaling Conference, 1946):

2. It is forbidden to take or kill gray whales or right whales except by aborigines or a contracting government on behalf of aborigines and only when the meat and products of such whales are to be used exclusively for local consumption by the aborigines.

\section{FORMALIZING THE MANAGEMENT OF ABORIGINAL WHALING}

The nature of managing aboriginal whaling began changing significantly in the mid 1970s when the commission's scientific committee began reporting on problems in the Alaskan Eskimo hunt for the Bering-Chukchi-Beaufort Seas stock of bowhead whales. While historical annual landings in this hunt during 1945-1969 had not exceeded 23 bowheads and averaged only 10, during 1970-1977 the annual landings had exceeded 23 bowheads six times and averaged 30 (Tillman, 1980). In addition to landed whales, the number of struck and lost whales had also increased dramatically each year from 10 in 1973 to a high of 82 in 1977, and the fate of such whales was problematic since it was unknown how many had been injured severely enough to die (Tillman, 1980). Matters came to a head at the 1977 annual meeting when the first tentative assessment efforts suggested a best estimate of current abundance of 1,300 animals versus an estimated original stock size of 11,700-18,000, implying that the population had declined to $7-11 \%$ of its original abundance (Tillman, 1980). Given this apparent degree of endangerment in the face of an expanding hunt, the scientific committee concluded that any taking could adversely affect the stock and contribute to preventing its eventual recovery, and recommended that on biological grounds this hunt should cease (IWC, 1978a). The commission agreed and deleted the words "or right" from the aboriginal exemption for right and gray whales (schedule paragraph 2), removing the legal basis for the hunt (IWC, 1978b).

The commission's decision fomented a domestic crisis within the U.S. under whose auspices the Alaskan Eskimo hunt was undertaken (Tillman, 1980). Fortunately, the circumstance of a special meeting of the IWC in late 1977 on North Pacific sperm whales (Physeter macrocephalus) provided an opportunity for the U.S. to reopen the bowhead issue. The U.S. strategy was to propose restoration of a limited hunt, with limits on numbers struck, as well as those landed, to satisfy the Eskimo's subsistence and cultural needs; the U.S. also committed to undertaking a major new domestic research and management program intended to provide for the science-based management of the bowhead hunt (Tillman, 1980). Upon reviewing the U.S. proposal, the scientific committee reiterated its earlier finding that on biological grounds the hunt should not be allowed, but also recognized that the IWC might wish to consider subsistence or cultural needs that were beyond the scientific committee's expertise (IWC, 1979a). Taking account of the scientific committee's advice and the representations of the U.S., the IWC ultimately revised its earlier decision, restoring the hunt for the 1978 season and approving a small take of 12 whales landed or 18 struck, whichever occurred first, and provided that no calves nor any bowhead whale accompanied by a calf were struck, taken, or killed (IWC, 1979b). 
In contrast to commercial whaling for which IWC had adopted a formal management structure into the schedule in 1975 (IWC, 1977), the management of aboriginal whaling continued in an ad hoc fashion for a number of years, as exemplified after 1977 by ensuing annual adjustments to the quotas for the bowhead hunt and, in 1978, by the setting of the first catch limit for the Russian hunt for Eastern North Pacific gray whales (IWC, 1979c). The IWC was unsatisfied with such an approach, since under the commercial scheme the management policy for whale stocks had become more and more cautious to allow for assessment uncertainties and to ensure that no stock was unwittingly reduced, especially if there was a very real risk of extinction (Gambell, 1982). Consequently, there was a desire to develop management principles and guidelines parallel to those reflected in the schedule for commercial whaling.

Hindering progress on this task, however, was IWC's lack of underpinnings for aboriginal whaling, including appropriate definitions, e.g., what was aboriginal whaling, or what was subsistence use? The Panel Meeting of Experts on Aboriginal/Subsistence Whaling in 1979 provided a working definition of "subsistence use" (IWC, 1982), as shown in Appendix 1, although this was not formally adopted by IWC until 2004 (IWC, 2005). Also in 1979, the IWC began requiring that the U.S. document the nutritional, cultural, and subsistence needs of the Alaskan Eskimos for bowhead whales (IWC, 1980), and in 1980 extended that requirement to all member governments having aboriginal hunts under their jurisdiction (IWC, 1981b). In 1981, the Ad Hoc Technical Committee Working Group on Development of Management Principles and Guidelines for Subsistence Catches of Whales by Indigenous (Aboriginal) Peoples developed the definitions, shown in Appendix 2, that were applicable to the range of aboriginal whaling activities then considered by the IWC (IWC, 1981a). Finally, the working group also developed objectives for the management of whale stocks subjected to aboriginal subsistence whaling, as given in Appendix 3 (IWC, 1981a).

The IWC accepted the working group's definitions in 1982, adopted into the schedule a management scheme for aboriginal whaling based upon them, and established a standing sub-committee of the technical committee (TC) to consider documentation on nutritional, subsistence, and cultural needs relating to aboriginal whaling and the uses of whales taken for such purposes, and to provide advice to the TC for its consideration and determination of appropriate management measures (IWC, 1983). Consequently, all of the elements required for a formal management process were then in place. Member nations with aboriginal hunts would be expected to submit documentation outlining the needs of their aboriginal peoples. The new Aboriginal Subsistence Whaling Sub-Committee would review that documentation and, taking account of any other factors, would report to the TC. The scientific committee would assess the status of the affected stocks, taking account of the principles set out in the schedule, and would also provide its advice to the TC. Taking account of all relevant information provided to it, the TC would then formulate management advice for the IWC's consideration and action. (Since under current procedures the TC is inactive, the IWC itself has assumed these responsibilities.)

It is informative to contrast the schedule provisions for commercial and aboriginal whaling that were in effect in 1982. Appendix 4 shows the aboriginal whaling management principles incorporated as paragraph 13(a) of the schedule (Wallace, 1994f). Under commercial whaling (paragraphs 10(a)-(c) of the current schedule), no catches of whales were permitted for any stock that was below the "protection" stock level defined as $10 \%$ of MSY stock level below the MSY stock level (Young, 1992), i.e., 90\% of that population level which produces the stock's maximum sustainable yield, or MSY. Under aboriginal whaling, however, catches were possible for stocks below the protection level. The applicable aboriginal provision only stipulated that such catches be of a size that would allow the whale stocks to move to the MSY stock level (i.e., to recover). Secondary requirements stipulated that, for each such stock, a minimum stock level should be set below which whales should not be taken, as well as a rate of population increase toward the MSY stock level. As noted earlier, since commercial whaling had depleted a number of stocks subject to aboriginal whaling, these provisions made it possible for existing aboriginal hunts to take place under circumstances that were not permitted for commercial whaling. Moreover, in the case of the bowhead hunt, the IWC took a substantial biological risk, despite the advice of the scientific committee, that continuing the hunt could prevent the recovery of the stock. Even more extraordinary is that the IWC had adopted the management regime for aboriginal whaling in the same year, 1982, that it had adopted a moratorium on commercial whaling (that became effective three years later) (IWC, 1983).

This difference in formal management regimes again shows that the IWC undertook risks for aboriginal whaling that it had not for commercial operations. Furthermore, the scientific committee had explicitly recognized that, besides scientific advice, the IWC might wish to discuss other considerations, such as subsistence and cultural needs that were beyond the committee's expertise, when developing appropriate management actions for aboriginal whaling. This explicit statement paved the way for the creation of the Aboriginal Subsistence Whaling Sub-Committee and the IWC's formal process for dealing with aboriginal whaling.

\section{RECENT DEVELOPMENTS IN MANAGING ABORIGINAL WHALING}

Two issues currently remain in play at IWC that touch upon the management of aboriginal whaling. First, since the implementation of the commercial moratorium in 1986, Japan has sought means by which its small-type coastal whaling (STCW) operations for minke whales (Balaenoptera acutorostrata) might continue to operate, claiming that, aside from certain commercial aspects, these operations shared many of the same characteristics as aboriginal whaling. IWC accordingly 
reconsidered its aboriginal whaling definitions (Appendix 2) to see if they might be appropriately modified to accommodate Japan's concerns (IWC, 1988). In 1988, however, IWC decided not to change the aboriginal definitions nor to make any additions to the category of aboriginal subsistence whaling, primarily because Japan's STCW did contain commercial features (IWC, 1989), which presumably exceeded those covered by the IWC's definition of "subsistence use" (Appendix 1). IWC instead decided to refer the matter to a new technical committee working group on small-type whaling to consider how the issue might be dealt with (IWC, 1989). The issue remains unresolved, however, and those deliberations continue to the present in one form or another.

Interestingly, contemporaneous with its first consideration of Japan's STCW proposal, the IWC also reviewed a proposal by St. Vincent and the Grenadines, to establish a catch limit for the artisanal hunt undertaken by its nationals on the island of Bequia (IWC, 1987). In 1987, the IWC unanimously recognized the Bequian hunt's aboriginal subsistence nature and set a small catch limit for North Atlantic humpbacks (IWC, 1988).

The second major issue touching upon aboriginal whaling involved the IWC's desire to revamp its management procedure for commercial whaling following the adoption of the commercial whaling moratorium. The scientific committee undertook this work as a part of the comprehensive assessment mentioned in the commercial moratorium provision (see schedule paragraph 10(e) in Young, 1992), and in 1994 the commission adopted the Revised Management Procedure (RMP) in principle but did not enter it into the schedule, pending the completion of an effective inspection and observation scheme, among other matters (IWC, 1995a). Upon adopting the RMP, the IWC also agreed that the scientific committee should investigate potential management regimes for aboriginal whaling, including regimes based on the approach taken in its development of the RMP (IWC, 1995b). The scientific committee has continued its work on developing an appropriate Aboriginal Whaling Management Procedure (AWMP), and IWC adopted the strike limit algorithms (the scientific component of the AWMP) for bowheads in 2002 (IWC, 2003) and for gray whales in 2004 (IWC, 2005).

It is revealing to contrast the objectives established by the IWC as guidance for the scientific committee's respective developments of the RMP and AWMP. In 1987, IWC accepted the three objectives for commercial management developed by the scientific committee, shown in Appendix 5 (IWC, 1990). In 1989, IWC assigned highest priority to commercial objective (2) on the depletion of stocks (IWC, 1990). With respect to aboriginal whaling, IWC in 1994 reiterated the management objectives it had adopted earlier (see Appendix 3) and directed the scientific committee to also account for the management principles previously incorporated into the schedule (see Appendix 4) (IWC, 1995b). So, although in 1996, IWC accorded highest priority to aboriginal objective (1) on not increasing the risks of extinction (IWC, 1997), it had earlier directed the scientific committee to account for the possibility of taking whales from depleted stocks. While the two management schemes would therefore share a common conservation goal that the risks of extinction not be increased by exploitation, they would nonetheless differ greatly in their treatment of depleted stocks. Moreover, other distinctions are found in the two schemes' remaining objectives. The commercial objectives dealt solely with contributing to the betterment of the industry, i.e., stable catches at the highest possible continuing level. On the other hand, one of the remaining aboriginal objectives addressed the conservation issue of allowing for the highest net recruitment to speed recovery, while the other called for meeting the cultural and nutritional needs of the aboriginal communities.

Therefore, in developing its future management schemes, IWC apparently would accommodate the risk of allowing aboriginal hunts on depleted stocks by requiring that the AWMP fulfill a second conservation objective that was not required of the RMP. Moreover, IWC made explicitly clear that any operation having commercial features beyond those it would accommodate under its definition of subsistence use (Appendix 1) should not be accorded status as aboriginal whaling. The distinction between commercial and aboriginal whaling is further shown in the non-conservation objectives of the RMP and the AWMP. That is, the commercial objective is broadly to maximize the available catch (obtain as much as one can), while the aboriginal objective is to satisfy subsistence needs in perpetuity (obtain only as much as one needs).

\section{DISCUSSION}

The history of managing aboriginal whaling clearly shows that international managers have been willing to take conservation risks for aboriginal hunts that they would not be willing to take for commercial operations. This risk-taking has been especially true with respect to the implementation of the 1946 convention that considered its aboriginal whaling provisions to be an integral part of the convention. Whereas commercial whalers have not been allowed to hunt whales from depleted stocks, aboriginal hunters have enjoyed that privilege, even since 1931, and the IWC has repeatedly endorsed that practice. Even the IWC's scientific committee has explicitly recognized that, besides information on the status of stocks, the IWC might wish to take account of other considerations, such as cultural and subsistence needs in formulating management actions. Another point is that, while aboriginal whaling has been allowed to operate despite conservation risks, such hunts nonetheless have also been required to adhere to additional conservation provisions that were not applied to commercial operations. For example, aboriginal catch limits have often been expressed in terms of whales struck, as well as those landed.

Although the record does not explicitly explain why such conservation risks have been accepted, it apparently arises from a commonly shared belief that, whereas commercial operations are driven by market forces to maximize catches, aboriginal hunts tend to be self-limiting in that they only take what is necessary to satisfy basic human needs. Accordingly, subsistence 
catches tend to remain relatively small. The IWC has also tried to ensure that, as far as possible, commercial elements are held in check and that aboriginal whaling does not stray far from the accepted definition of subsistence use.

The Government of Japan (1987) has commented, however, that IWC's definitions are not clear-cut and has further observed that the nature of the existing aboriginal hunts has evolved due to increases in native populations and changing technology. Moreover, Reeves (2002), has commented about IWC's contemporary difficulties in managing aboriginal whaling, noting "... the distinction between commercial and subsistence remains crude and ambiguous." Nevertheless, IWC has had some practical experience sorting out these differences, if only politically, rejecting STCW as meeting the aboriginal criteria in 1988 but accepting as doing so the Bequian hunt in 1987 and the Makah Indian Tribe's hunt for gray whales off Washington State in 1997 (IWC, 1998), although not without controversy in the latter case (Reeves, 2002).

While some may argue that the IWC's aboriginal management approach is flawed, the true measure of its success or failure should be in terms of how well it has met its conservation goals. At its annual meeting in 2007, the scientific committee advised the commission that most of the stocks subject to aboriginal whaling have not been disadvantaged by their respective hunts and, indeed, that current strike limits are sustainable (IWC, 2007a). Assessments for humpback and bowhead whales off West Greenland, however, currently are problematic (IWC, 2007a), and in 2007 IWC accordingly did not set a strike limit for humpbacks and that for bowheads requires further advice from the scientific committee prior to implementation (IWC, 2007b). It would thus appear that the aboriginal hunters for the most part have behaved responsibly and that IWC's approach for dealing with them over the past 60 years has been successful from a conservation perspective.

\section{ACKNOWLEDGMENTS}

I am grateful to J. G. Mead (Smithsonian Institution National Museum of Natural History) who helped me gain access to the Remington Kellogg Collection within the Archives and Special Collections of the Smithsonian Institution (Smithsonian Institution, 1996). R. Schmitten provided needed encouragement that led to the completion of the article. R. Brownell and J. Tichotsky, as well as two anonymous reviewers, provided useful comments that helped strengthen the article. Financial support for undertaking the research and preparing the article were provided by the National Marine Fisheries Service under purchase order nos. DG133F04SE0569 and DG133F06SE5491.

\section{REFERENCES}

Caulfield, R. A. Greenlanders, Whales, and Whaling: Sustainability and Self-Determination in the Arctic. University Press of New England, Hanover and London (1997).
Gambell, R. The bowhead whale problem and the International Whaling Commission. Rep. Int. Whal. Comm., Special Issue, 4: 1-6 (1982).

Gambell, R. International management of whales and whaling: An historical review of the regulation of commercial and aboriginal subsistence whaling. Arctic, 46: 97-107 (1993).

Gambell, R. Recent developments in IWC aboriginal subsistence whaling category. In: Whaling in the North Atlantic Economic and Political Perspectives (G. Petursdottir, Ed.). University of Iceland Press, Reykjavik (1997).

Government of Japan. History of the consideration of aboriginal/subsistence whaling. Unpublished document IWC/39/26 available from IWC Secretariat, Cambridge, UK (1987).

International Whaling Commission. Chairman's Report of the 27th Meeting. Rep. Int. Whal. Comm., 27: 6-15 (1977).

International Whaling Commission. Report of the Scientific Committee. Rep. Int. Whal. Comm., 28: 38-92 (1978a).

International Whaling Commission. Chairman's Report of the 29th Meeting. Rep. Int. Whal. Comm., 28: 18-37 (1978b).

International Whaling Commission. Report of the Scientific Committee. Rep. Int. Whal. Comm., 29: 38-105 (1979a).

International Whaling Commission. Chairman's Report of the Special Meeting, Tokyo, December 1977. Rep. Int. Whal. Comm., 29: 2-6 (1979b).

International Whaling Commission. Chairman's Report of the 30th Annual Meeting. Rep. Int. Whal. Comm., 29: 21-37 (1979c).

International Whaling Commission. Chairman's Report of the 31st Annual Meeting, Appendix 4, Resolution on Bering Sea Bowheads. Rep. Int. Whal. Comm., 30: 25-41 (1980).

International Whaling Commission. Report of the Ad Hoc Technical Committee Working Group on Development of Management Principles and Guidelines for Subsistence Catches of Cetaceans by Indigenous (Aboriginal) Peoples. Unpublished Document IWC/33/14 available from IWC Secretariat, Cambridge, UK (1981a).

International Whaling Commission. Chairman's Report of the 32nd Annual Meeting, Appendix 3, Resolution on the Documentation of Aboriginal Need. Rep. Int. Whal. Comm., 31: 17-40 (1981b).

International Whaling Commission. 1982. The Report of the Cultural Anthropology Panel, Appendix 1. Rep. Int. Whal. Comm. Special Issue, 4: 35-49 (1982).

International Whaling Commission. Chairman's Report of the 34th Annual Meeting. Rep. Int. Whal. Comm., 33: 20-42 (1983).

International Whaling Commission. Chairman's Report of the 38th Annual Meeting. Rep. Int. Whal. Comm., 37: 10-27 (1987).

International Whaling Commission. Chairman's Report of the 39th Annual Meeting. Rep. Int. Whal. Comm., 38: 10-31 (1988).

International Whaling Commission. Chairman's Report of the 40th Annual Meeting. Rep. Int. Whal. Comm., 39: 10-32 (1989).

International Whaling Commission. Chairman's Report of the 41st Annual Meeting. Rep. Int. Whal. Comm., 40: 11-37 (1990).

International Whaling Commission. Chairman's Report of the 46th Annual Meeting, Appendix 5, Resolution on the Revised Management Scheme. Rep. Int. Whal. Comm., 45: 15-52 (1995a).

International Whaling Commission. Chairman's Report of the 46th Annual Meeting, Appendix 4, Resolution on a Review of the Aboriginal 
Subsistence Management Procedure. Rep. Int. Whal. Comm., 45: 1552 (1995b).

International Whaling Commission. Chairman's Report of the 48th Annual Meeting. Rep. Int. Whal. Comm., 47: 17-55 (1997).

International Whaling Commission. Chairman's Report of the 49th Annual Meeting. Rep. Int. Whal. Comm., 48: 17-51 (1998).

International Whaling Commission. Chairman's Report of the 44th Annual Meeting. Rep. Int. Whal. Comm., 2002: 5-53 (2003).

International Whaling Commission. Chairman's Report of the 56th Annual Meeting. Rep. Int. Whal. Comm., 2004: 5-58 (2005).

International Whaling Commission. Report of the Scientific Committee. Unpublished Document IWC/59/Rep 1, available from IWC Secretariat, Cambridge, UK (2007a).

International Whaling Commission. Proposed Schedule Amendment (Greenland Catch Limits). Unpublished Document IWC/59/23 Rev. 3, available from IWC Secretariat, UK (2007b).

International Whaling Conference. Final Act and Verbatim Minutes of the Conference, Washington, DC, November 20-December 2, 1946. Unpublished conference documents available from the Archives and Special Collections of the Smithsonian Institution, Washington, DC. [See Box 10, Folder 5, in Record Unit 7165, International Whaling Conference and International Whaling Commission, 1930-1968, Remington Kellogg Collection] (1946).

Kapel, F.O. and R. Petersen. Subsistence hunting-the Greenland case. Rep. Int. Whal. Comm. Special Issue, 4: 51-74 (1982).

Mackintosh, N. A. The Stocks of Whales. Fishing News (Books) Ltd., London (1965).

Reeves, R. R. The origins and character of "aboriginal subsistence" whaling: A global review. Mammal Rev., 32: 71-106 (2002).

Smithsonian Institution. Guide to the Smithsonian Archives. Archives and Special Collections of the Smithsonian Institution: No. 5 (1996).

Tillman, M. F. Introduction: A scientific perspective of the bowhead whale problem. Mar. Fish. Rev., 42: 2-5 (1980).

Wallace, R. C. Convention for the Regulation of Whaling, Geneva, 1931, pp. 1394-1399. In: The Marine Mammal Commission Compendium of Selected Treaties, International Agreements, and Other Relevant Documents on Marine Resources and the Environment. Washington, DC: U.S. Government Printing Office, 1994-337-624, Vol. II: 1121-2342 (1994a).

Wallace, R. C. International Convention for the Regulation of Whaling, Washington, DC, 1946, pp. 1400-1407. In: The Marine Mammal Commission Compendium of Selected Treaties, International Agreements, and Other Relevant Documents on Marine Resources and the Environment. Washington, DC: U.S. Government Printing Office, 1994-337-624, Vol. II: 1121-2342 (1994b).

Wallace, R. C. Amendments to the Schedule to the International Convention for the Regulation of Whaling, Tokyo, 1954, pp. 14241431. In: The Marine Mammal Commission Compendium of Selected Treaties, International Agreements, and Other Relevant Documents on Marine Resources and the Environment. Washington, DC: U.S. Government Printing Office, 1994-337-624 Vol. II: 1121-2342 (1994c).

Wallace, R. C. Amendments to the Schedule to the International Convention for the Regulation of Whaling, London, 1961, pp. 14511452. In: The Marine Mammal Commission Compendium of Selected
Treaties, International Agreements, and Other Relevant Documents on Marine Resources and the Environment. Washington, DC: U.S. Government Printing Office, 1994-337-624 Vol. II: 1121-2342 (1994d).

Wallace, R. C. Amendments to the Schedule to the International Convention for the Regulation of Whaling, London, 1964, pp. 14561459. In: The Marine Mammal Commission Compendium of Selected Treaties, International Agreements, and Other Relevant Documents on Marine Resources and the Environment. Washington, DC: U.S. Government Printing Office, 1994-337-624, Vol. II: 1121-2342 (1994e).

Wallace, R. C. Amendments to the Schedule to the International Convention for the Regulation of Whaling, Brighton, 1982, pp. 15461548. In: The Marine Mammal Commission Compendium of Selected Treaties, International Agreements, and Other Relevant Documents on Marine Resources and the Environment. Washington, DC: U.S. Government Printing Office, 1994-337-624, Vol. II: 1121-2342 (1994f).

Young, N. (Ed.). Understanding the Revised Management Procedure, Appendix B-Schedule. Center for Marine Conservation, Washington, DC (1992).

\section{APPENDIX 1. DEFINITION OF SUBSISTENCE USE (IWC, 1982)}

1. The personal consumption of whale products for food, fuel, shelter, clothing, tools, or transportation by participants in the whale harvest.

2. The barter, trade, or sharing of whale products in their harvested form with relatives in the harvest, with others in the local community, or with persons in locations other than the local community with whom residents share familial, social, cultural, or economic ties. A generalized currency is involved in this barter and trade, but the predominant portion of the products from each whale are ordinarily directly consumed or utilized in their harvested form within the local community.

3. The making and selling of handicraft articles from whale products when the whale is harvested for the purpose defined in 1 and 2 above.

\section{APPENDIX 2. DEFINITIONS FOR ABORIGINAL SUBSISTENCE WHALING (IWC, 1981a)}

1. Aboriginal subsistence whaling means whaling for purposes of local consumption carried out by or on behalf of aboriginal, indigenous, or native peoples who share strong community, familial, social, and cultural ties related to a continuing traditional dependence on whaling and on the use of whales.

2. Local aboriginal consumption means the traditional uses of whale products by local aboriginal, indigenous, or native communities in meeting their nutritional, subsistence, and cultural requirements. The term includes trade in items which are by-products of subsistence catches.

3. Subsistence catches are catches of whales by aboriginal subsistence whaling operations. 


\section{APPENDIX 3. OBJECTIVES FOR MANAGING ABORIGINAL SUBSISTENCE WHALING (IWC, 1981a)}

1. To ensure that the risks of extinction to individual stocks are not seriously increased by subsistence whaling;

2. To enable aboriginal people to harvest whales in perpetuity at levels appropriate to their cultural and nutritional requirements, subject to other objectives;

3. To maintain the status of whale stocks at or above the level giving the highest net recruitment and to ensure that stocks below that level are moved towards it, so far as the environment permits.

\section{APPENDIX 4. PRINCIPLES FOR MANAGING ABORIGINAL SUBSISTENCE WHALING INCORPORATED AS PART OF THE SCHEDULE (WALLACE, 1994f)}

1. For stocks at or above the MSY level, aboriginal subsistence catches shall be permitted so long as total removals do not exceed $90 \%$ of MSY.
2. For stocks below the MSY level but above a certain minimum level, aboriginal subsistence catches shall be permitted so long as they are set at levels which will allow whale stocks to move to the MSY level.

3. The above provisions will be kept under review, based upon the best scientific advice, and by 1990 at the latest the commission will undertake a comprehensive assessment of the effects of these provisions on whale stocks and consider modification.*

\section{APPENDIX 5. OBJECTIVES FOR COMMERCIAL MANAGEMENT (IWC, 1990)}

1. Stability of catch limits, which would be desirable for the orderly development of the whaling industry.

2. Acceptable risk that a stock not be depleted (at a certain level of probability) below some chosen level (e.g., a fraction of its carrying capacity), so that the risk of extinction is not seriously increased by exploitation.

3. Making possible the highest possible continuing yield from the stock.
*The commission, on advice of the scientific committee, shall establish as far as possible (a) a minimum stock level for each stock below which whales shall not be taken, and (b) a rate of increase towards the MSY level for each stock. The scientific committee shall advise on a minimum stock level and on a range of rates of increase towards the MSY level under different catch regimes. 